7th International Symposium on Superalloy 718 and Derivatives Edited by: E.A. Ott, J.R. Groh, A. Banik, I. Dempster, T.P. Gabb, R. Helmink, X. Liu, A. Mitchell, G.P. Sjöberg, and A. Wusatowska-Sarnek TMS (The Minerals, Metals \& Materials Society), 2010

\title{
RESEARCH ON INCONEL 718 TYPE ALLOYS WITH IMPROVEMENT OF TEMPERATURE CAPABILITY
}

\author{
Shuhong Fu ${ }^{1,2}$, Jianxin Dong ${ }^{1}$, Maicang Zhang ${ }^{1}$, Ning Wang ${ }^{3}$, Xishan Xie ${ }^{1}$ \\ ${ }^{1}$ High Temperature Materials Research Laboratories, \\ University of Science \& Technology Beijing; Beijing 100083, China \\ ${ }^{2}$ National Key Laboratory of Science and Technology \\ on Advanced High Temperature Structural Materials \\ Beijing Institute of Aeronautical Materials, Beijing 100095, China \\ ${ }^{3}$ Baosteel Group Corporation, No.1269 Shuichan Road, Shanghai, 200940, China
}

Keywords: 718 type alloys, Temperature capability, $\delta$ phase

\begin{abstract}
Inconel 718 was developed by International Nickel Company in 1962, has become the most widely used superalloy in the world. The alloy's popularity is due to its excellent combination of mechanical properties, moderate price and good processability. However, its maximum use temperature is restricted to $650^{\circ} \mathrm{C}$ because the main strengthening $\gamma^{\prime \prime}$ phase responsible for the alloy's outstanding properties rapidly overages. There has been a substantial amount of work by numerous investigations over the years to increase the temperature capability of Inconel 718. Xie and Dong et al. has systematically studied the effect of variation of alloying elements including $\mathrm{Al}, \mathrm{Ti}, \mathrm{Nb}, \mathrm{P}, \mathrm{B}, \mathrm{S}$ and $\mathrm{Mg}$ etc. content on structural stability and mechanical properties by experiments and thermodynamic calculations.

This attempt was made to improve the temperature capability of Inconel 718 via controlling the morphology of $\gamma^{\prime \prime}$ and $\gamma^{\prime}$ phase and increase their solvus temperature by variation of $\mathrm{Al}, \mathrm{Ti}$ and $\mathrm{Nb}$ content, and $\mathrm{W}$ addition for solid solution strengthening. The phases precipitation behaviors, long time microstructure stability and mechanical properties of modified 718 type alloys have been systematically studied. The results indicate that compact morphology of $\gamma^{\prime \prime}$ and $\gamma^{\prime}$ has been observed in grains. In addition, a new stable globular phase with higher solvus temperature mainly precipitated at grain boundaries, different to the $\delta$ phase in conventional 718 alloy, has been observed in modified 718 type alloys (this phase is temporarily named $\delta^{\prime \prime}$ phase for description convenience). After $680^{\circ} \mathrm{C}$ aging for $1,000 \mathrm{~h}$, the combination of $\delta^{\prime \prime}$ granular phase at grain boundaries and compact morphology precipitation of $\gamma^{\prime \prime}$ and $\gamma^{\prime}$ phase in grains characterize with superior thermal stability. Preliminary mechanical properties test results show that the alloy with this kind of microstructure can provide better stress rupture properties and fatigue resistance than that of conventional Inconel 718. It appears to provide a new approach for improvement of temperature capability of Inconel 718 and the new designed 718 type alloy can be used at $680^{\circ} \mathrm{C}$ or higher temperatures.
\end{abstract}

\section{Introduction}

Inconel 718 is a nickel-base superalloy strengthened mainly by $\mathrm{Ni}_{3} \mathrm{Nb}$ type $\gamma^{\prime \prime}$ and partially by $\mathrm{Ni}_{3} \mathrm{Al}$ type $\gamma^{\prime}$ precipitation. Since Inconel 718 entered production, it experienced a period of 
rapid growth and application into a broad range of high temperature industries due to its unique characteristics and affordability. Inconel 718 is still today's most widely used superalloy in the world [1,2]. Despite the enormous success of Inconel 718, current applications of Inconel 718 are still limited because of the metastability of $\gamma^{\prime \prime}$-strengthening system and it can not be used at temperatures higher than $650^{\circ} \mathrm{C}$. However, the rapid development of aero-engines has led to stringent requirements of the alloy that can be used at $680 \sim 700^{\circ} \mathrm{C}$, and meanwhile characterizes with superior microstructure stability after long time service, good formability and weldability.

Numerous attempts have been made over the past several decades to improve temperature capability of Inconel 718, typically through chemistry modifications involving adjustment the content of $\mathrm{Al}, \mathrm{Ti}$ and $\mathrm{Nb}$ and minor elements such as $\mathrm{P}$ and $\mathrm{B}$. Cozar and Pineau firstly developed the compact morphology of $\gamma^{\prime \prime}$ and $\gamma^{\prime}$ by adjustment $\mathrm{Nb}$, Ti and $\mathrm{Al}$ content and their ratios, and found this special compact microstructure characterized with superior structure stability than that of the separated precipitation of $\gamma^{\prime \prime}$ and $\gamma^{\prime}[3,4]$. Subsequently, Tien, Guo, Radavich and Chang et al. adjusted the $\mathrm{Al} / \mathrm{Ti}$ ratio and $(\mathrm{Al}+\mathrm{Ti}) / \mathrm{Nb}$ ratio based on conventional Inconel 718 alloy, and the experimental results indicate that higher $\mathrm{Al} / \mathrm{Ti}$ ratio and $(\mathrm{Al}+\mathrm{Ti}) / \mathrm{Nb}$ ratio can remarkably improve the structure stability of 718 alloy [5-15]. However, these experimental results mainly concentrate on the importance of $\gamma^{\prime \prime}$ and $\gamma^{\prime}$ stability during long time aging and neglect other phases precipitation behavior. Cao and Kennedy developed Allvac 718ER alloy by increasing $\mathrm{P}$ and $\mathrm{B}$ content and expectation of the modified 718 alloy to be used at $700^{\circ} \mathrm{C}$, but it appeared that $\mathrm{P}$ and $\mathrm{B}$ modification did not have a noticeable effect on microstructural stability at $700^{\circ} \mathrm{C} / 1,000 \mathrm{~h}$ aging and the improvement in temperature capability is not greater than $25^{\circ} \mathrm{C}[16,17]$. Hu et al. developed a modified 718 alloy by just keeping higher content of $\mathrm{P}$ and $\mathrm{B}$ and the experimental results indicate that this alloy can be used at $680^{\circ} \mathrm{C}[18$ 19]. Xie and Dong et al. has systematically studied the effect of alloying elements including Al, $\mathrm{Ti}, \mathrm{Nb}, \mathrm{P}, \mathrm{B}, \mathrm{S}$, and $\mathrm{Mg}$ etc. in Inconel 718 alloy on structure stability and mechanical properties. The results reveal that increasing Al content can obviously increase $\gamma^{\prime} / \gamma^{\prime \prime}$ solvus temperature and improve structure stability of 718 alloy. Higher Ti content will result in large amount of $\eta$ phase formation. Higher $\mathrm{Nb}$ content can remarkably improve the strength of alloy 718[20-22]. The combination of $0.012 \sim 0.015 \% \mathrm{P}$ with $0.005 \sim 0.01 \% \mathrm{~B}$ can noticeably improve the stress rupture life of alloy 718, but the structure stability can not be increased [23, 24]. Recently, Allvac has developed 718Plus with 10\% Co addition and adjustment of $\mathrm{Al}$ and Ti contents, which appears to have achieving the goal of increasing the temperature capacity Inconel 718 by $50^{\circ} \mathrm{C}$ [25-27]. However, China is in shortage of cobalt. Therefore, the alloy without Co addition that can be used at $680^{\circ} \mathrm{C}$ or higher temperatures should be developed in China for domestic aviation and other industries.

\section{Materials and Experimental Procedure}

Previous Thermo-Calc calculation indicates that $\gamma^{\prime} / \gamma^{\prime \prime}$ solvus is $904^{\circ} \mathrm{C}$ for conventional Inconel 718 alloy. The effect of increasing Al content shows a strong increase in $\gamma / \gamma^{\prime \prime}$ solvus [28]. An increase of Ti content has a more mild effect on $\gamma^{\prime} / \gamma^{\prime \prime}$ solvus than Al. Niobium content should be kept at higher level to guarantee high strength. To improve the stress rupture properties, $\mathrm{P}$ and $\mathrm{B}$ should be kept at higher content. $\mathrm{W}$ is a strong solid solution element to strengthen the $\gamma$ matrix. Based on our experimental results, several modified 718 type alloys have been prepared for this investigation as 
shown in Table I. Alloy 1 is the conventional 718 alloy with $0.5 \% \mathrm{Al}$ and Alloy 2 is a modified 718 type alloy with higher $\mathrm{Al}$ content. Addition $1.5 \% \mathrm{~W}$ to Alloy 2 can get Alloy 3 . Alloy 4 has higher $\mathrm{Al}$ content in comparison with Alloy 2. Addition $1.5 \% \mathrm{~W}$ to Alloy 4 can get Alloy 5.

All these alloys were vacuum induction melted (VIM). Ingots were homogenized after conditioning. Homogenized ingots were then forged and heat treated. The heat treatment for these 718 type alloys was the standard routine heat treatment for conventional 718 alloy $\left(954^{\circ} \mathrm{C} / 1 \mathrm{~h}, \mathrm{AC}, 720^{\circ} \mathrm{C} / 8 \mathrm{~h}, \mathrm{FC} 50^{\circ} \mathrm{C} / \mathrm{h}\right.$ to $620^{\circ} \mathrm{C}$ and hold for $8 \mathrm{~h}$ at $\left.620^{\circ} \mathrm{C}, \mathrm{AC}\right)$. After heat treatment, these 718 type alloys were aging at $680^{\circ} \mathrm{C}$ for $100 \mathrm{~h} \sim 1,000 \mathrm{~h}$ to study the structure stability. For accelerated evaluation on long term structure stability, experimental thermal exposure was also conducted at higher temperature $760^{\circ} \mathrm{C}$ for $100 \mathrm{~h}$.

Table I. Chemical composition of 718 type alloys (wt \%)

\begin{tabular}{|c|c|c|c|c|c|c|c|c|c|c|c|c|}
\hline Alloy & $\mathrm{C}$ & $\mathrm{Ni}$ & $\mathrm{Fe}$ & $\mathrm{Cr}$ & $\mathrm{Mo}$ & $\mathrm{Al}$ & $\mathrm{Ti}$ & $\mathrm{Nb}$ & $\mathrm{W}$ & $\mathrm{S}$ & $\mathrm{P}$ & $\mathrm{B}$ \\
\hline 1 & 0.01 & Bal. & 18.4 & 18.99 & 3 & 0.55 & 0.98 & 5.52 & - & 0.003 & $<0.005$ & 0.002 \\
2 & 0.029 & Bal. & 18.3 & 18.9 & 2.95 & 1.1 & 1 & 5.5 & - & 0.001 & 0.014 & 0.007 \\
3 & 0.03 & Bal. & 18.55 & 18.72 & 3 & 0.94 & 0.93 & 5.52 & 1.49 & 0.004 & 0.02 & 0.002 \\
4 & 0.031 & Bal. & 18.55 & 18.78 & 3.01 & 1.24 & 0.93 & 5.16 & - & 0.002 & 0.024 & 0.009 \\
5 & 0.03 & Bal. & 18.4 & 18.68 & 2.95 & 1.4 & 0.91 & 5.51 & 1.51 & 0.002 & 0.02 & 0.002 \\
\hline
\end{tabular}

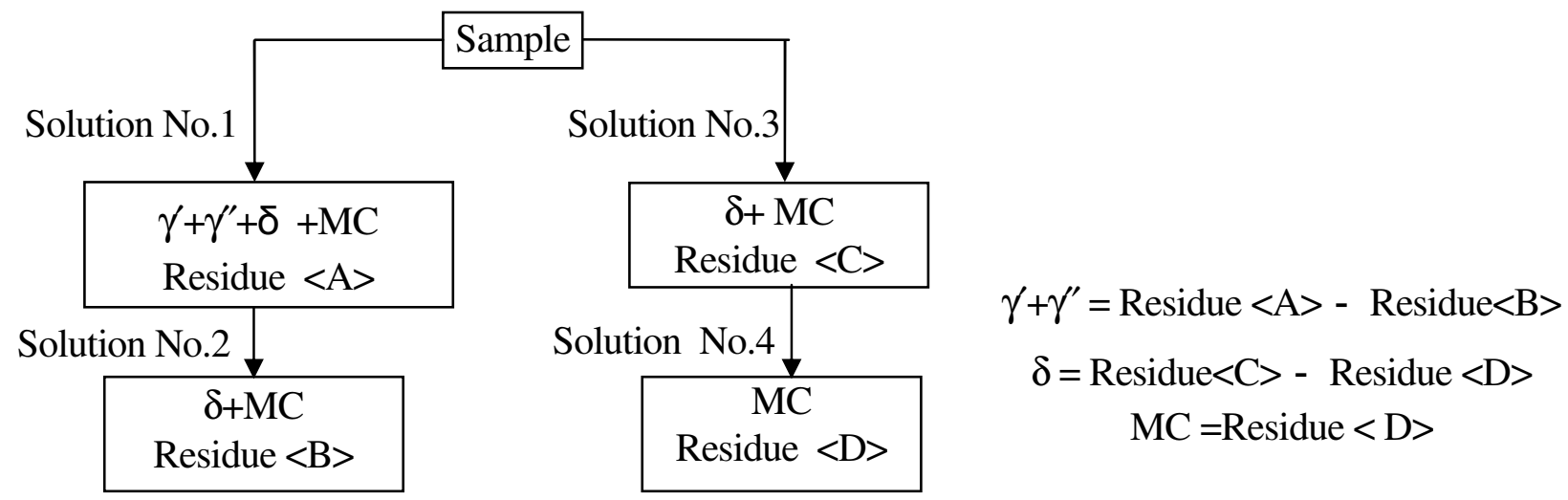

Fig.1 Procedure for phase extraction and separation

Table II Solutions and conditions for electrolytic extraction of phases in modified 718 type alloys

\begin{tabular}{|c|l|}
\hline Solution No. & \multicolumn{1}{|c|}{ Chemical compositions of solutions and electrolytic extraction conditions } \\
\hline 1 & $1 \%\left(\mathrm{NH}_{4}\right) \mathrm{SO}_{4}+2 \% \mathrm{C}_{4} \mathrm{H}_{6} \mathrm{O}_{6}+\mathrm{H}_{2} \mathrm{O} ; \mathrm{T}=10^{\circ} \mathrm{C}, \mathrm{i}=0.025 \sim 0.03 \mathrm{~A} / \mathrm{cm}^{2}$ \\
2 & $5 \% \mathrm{H}_{2} \mathrm{SO}_{4}+2 \sim 3 \% \mathrm{C}_{4} \mathrm{H}_{6} \mathrm{O}_{6}+\mathrm{H}_{2} \mathrm{O} ;$ Boiling water for 3 3.5h \\
3 & $5 \% \mathrm{HCl}+5 \% \mathrm{C}_{3} \mathrm{H}_{5}(\mathrm{OH})_{3}+1 \sim 2 \% \mathrm{C}_{6} \mathrm{H}_{8} \mathrm{O}_{7} \cdot \mathrm{H}_{2} \mathrm{O}+\mathrm{CH}_{3} \mathrm{OH} ;$ \\
4 & $\mathrm{~T}=-10 \sim-5{ }^{\circ} \mathrm{C}, \mathrm{i}=0.08 \sim 0.1 \mathrm{~A} / \mathrm{cm}^{2}$ \\
& $10 \sim 15 \% \mathrm{HCl}+2 \% \mathrm{C}_{4} \mathrm{H}_{6} \mathrm{O}_{6}+\mathrm{CH}_{3} \mathrm{CH}_{2} \mathrm{OH} ;$ Distillation \\
\hline
\end{tabular}

In order to identify the phases in these modified 718 type alloys, X-ray diffraction technique (XRD) and EDS were used. SEM was used to observe the morphology and distribution of the precipitated 
phases. Physico-chemistry phase analyses were used to conduct the quantitative determination and chemical composition of all phases in these alloys. The precipitated phases for X-ray diffraction studies were extracted electrolytically from the samples in different solutions for different phases. Fig.1 and Table II shows the method of phase extraction and separation used for XRD and microchemical phase analyses.

\section{Experimental Results}

\section{$\underline{\text { Microstructure of } 718 \text { Type Alloys at As-heat Treated Condition }}$}

Fig. 1 shows the microstructures of experimental alloys after fully heat treatment. Needle-like $\delta$ phase precipitation is distributed mainly at grain boundaries in conventional 718 Alloy 1 (Fig.1a). However, the morphology and distribution of phases in other alloys have obvious differences to those in Alloy 1. Firstly, the grain boundary phase that can be resolved in other alloys is in short rod or granular morphology, which is different to needle-like $\delta$ phase in conventional 718 Alloy 1 . Secondly, $\delta$ phase in Alloy 1 is mainly distributed at grain boundaries while short rod or granular phase in Alloy 3 is distributed not only at grain boundaries but also in the grains (Fig.2a, b). Moreover, except the granular phase, there are still some short needle-like phases distributed at grain boundaries in Alloy 3 and Alloy 4(Fig.2b, c), while there seems to be only short rod or granular phase in Alloy 5(Fig.2d).
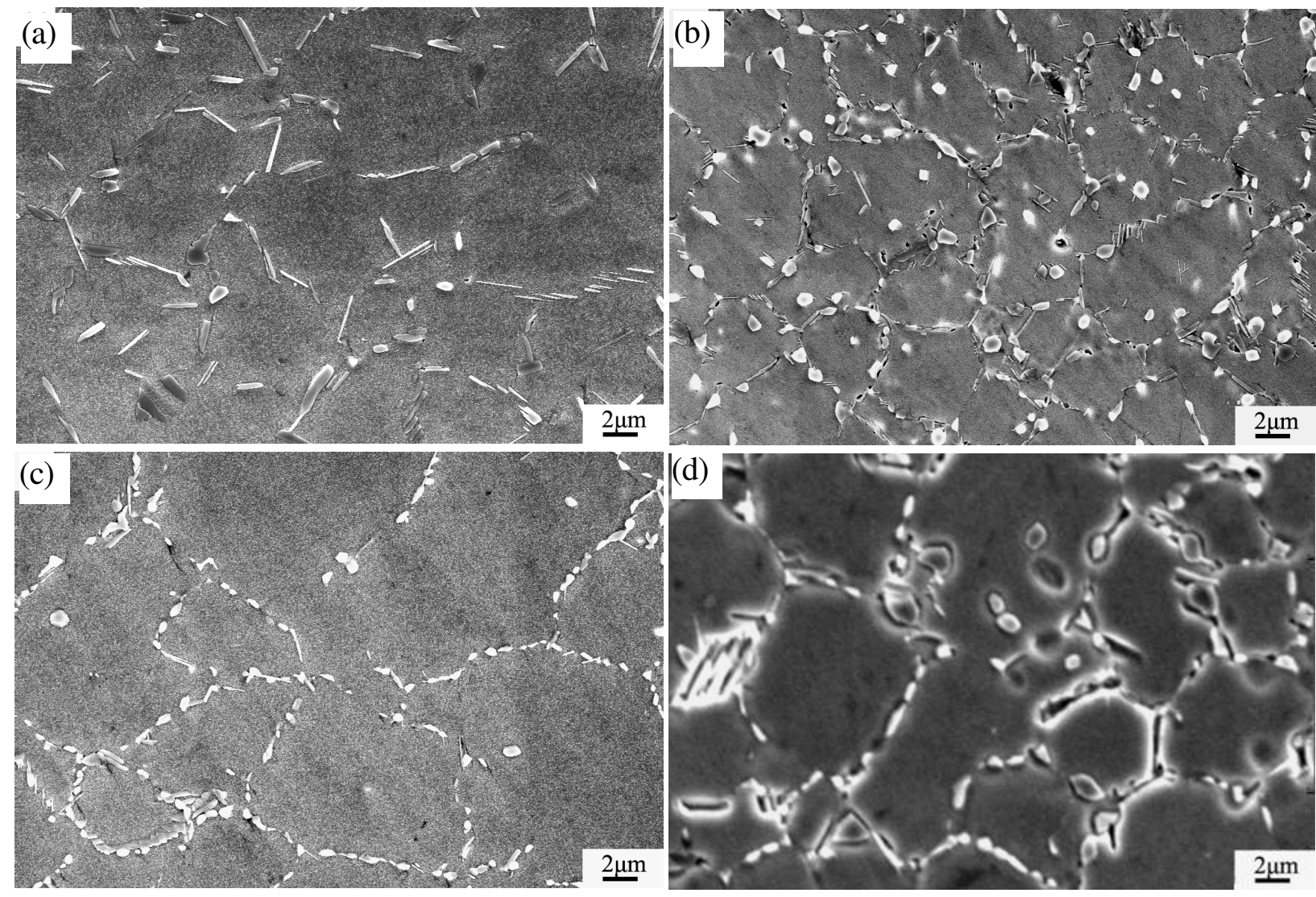

Fig. 2 SEM microstructures of (a)Alloy 1 (b)Alloy 3 (c)Alloy 4 (d)Alloy 5 at as-heat treated condition 
Long Time Structure Stability of 718 Type Alloys

Fig.3 reveals that during thermal exposure at $680^{\circ} \mathrm{C}$ for $1,000 \mathrm{~h}$, the main strengthening phase $\gamma^{\prime \prime}$ in Alloy 1 coarsen rapidly and has transformed to a considerable content of $\delta$ phase(Fig.3a). However, only a small amount of $\delta$ phase precipitate at grain boundaries in modified 718 type alloys (Fig.3c, e). The granular phase at grain boundaries is very stable after long time aging (this phase is temporarily named $\delta^{\prime \prime}$ phase for description convenience).
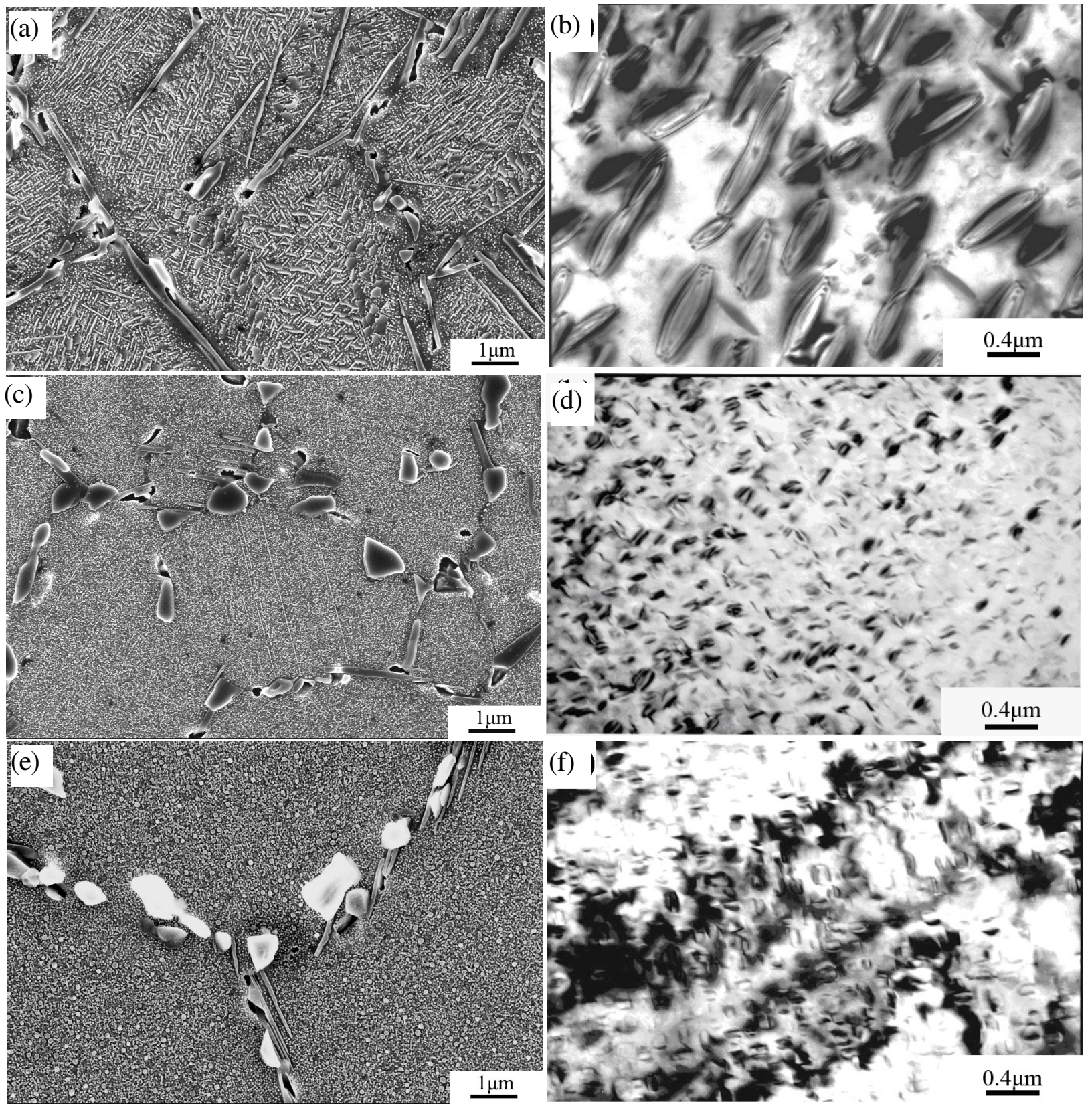

Fig. 3 SEM and TEM microstructures of Alloy 1: (a)(b); Alloy 3: (c)(d); Alloy 4: (e)(f) aging at $680^{\circ} \mathrm{C}$ for $1000 \mathrm{~h}$ 
In comparison with $\delta$ phase, $\gamma^{\prime \prime}$ and $\gamma^{\prime}$ in these modified type alloys are very fine therefore they are difficult to resolve via SEM. TEM analyses indicate that the morphology of strengthening phases after aging at $680^{\circ} \mathrm{C}$ for $1000 \mathrm{~h}$ are greatly different. It is clear that there are not disk-like precipitates of $\gamma^{\prime \prime}$ phase in modified 718 type alloys. Figure 3 shows that the coarsening of separately precipitated $\gamma$ and $\gamma^{\prime \prime}$ in conventional 718 Alloy 1 is more significant than that of associated precipitation or compact morphology of $\gamma^{\prime \prime}+\gamma^{\prime}$ in other 718 type alloys (Fig.3b, $d$ and f). Therefore, the coarsening rate of associated or compact morphology precipitated phases in other 718 type alloys is much lower than that of $\gamma^{\prime \prime}$ phase in alloy 1 with prolonging aging time. Fig.4 is the coarsening rate for $\gamma^{\prime \prime}$ and $\gamma^{\prime}$ phase $680^{\circ} \mathrm{C}$ aging at different times.
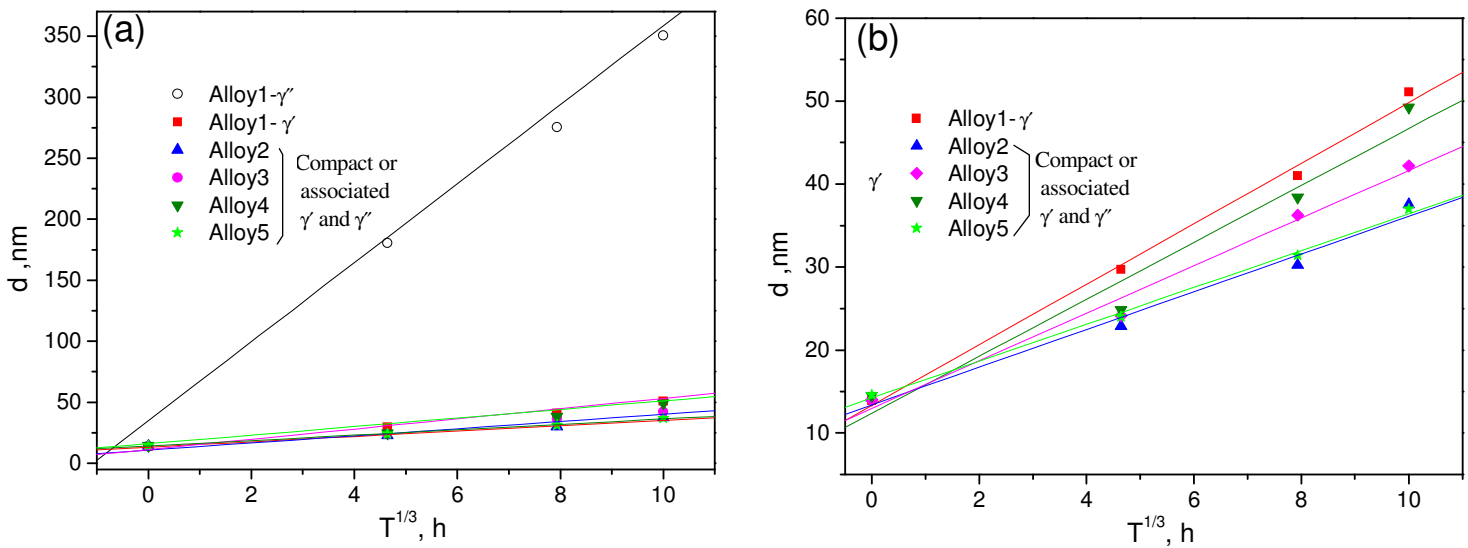

Fig. 4 The coarsening rate comparison of $\gamma^{\prime \prime}$ and $\gamma^{\prime}$ phases in conventional 718 Alloy 1 with other modified 718 type alloys at $680^{\circ} \mathrm{C}$ aging for different times

For accelerated evaluation on long term structure stability of these 718 type alloys, experimental thermal exposure was conducted at a higher temperature of $760^{\circ} \mathrm{C}$ for $100 \mathrm{~h}$ after fully heat treatment. From Fig.5 it can be seen that, for Alloy 1, large amounts of $\delta$ phase and the separate precipitation of $\gamma^{\prime \prime}$ phase coarsen significantly in comparison with the microstructure at as-heat treated condition (Fig.5 a and Fig.1 a). Fig.5 (a) shows that a considerable fraction of $\gamma^{\prime \prime}$ phase in alloy 1 has evolved into long needle $\delta$ phase and further exposure will accelerate it evolving into more severe Widmanstatten structure. However, there are significant differences in microstructures between conventional 718 Alloy 1 and the other modified 718 type alloys. After aging at $760^{\circ} \mathrm{C}$ for $100 \mathrm{~h}$, only a few needle-like phase precipitated at grain boundaries, which indicates great improvement on thermal structure stability because only a few of needle-like $\mathrm{Ni}_{3} \mathrm{M}$ phase formed at grain boundaries and in grains. The $\delta^{\prime \prime}$ phase can still keep discontinuous morphology after long time exposure demonstrating good thermal stability as it compares with the microstructure of 718 Plus with $10 \%$ Co addition (Fig. $5 \mathrm{~g}, \mathrm{~h}$ ).

Therefore, from these experimental results it can be concluded that the increase of Al content and $\mathrm{W}$ addition leads to improve structure stability after thermal exposure at higher temperatures.

\section{Phases Identification at Grain Boundaries for 718 Type Alloys}

Fig.1, Fig. 2 and Fig.5 show that in 718 type alloys the granular phase at grain boundary is different to needle-like $\delta$ phase in conventional 718 Alloy 1 and it characterizes with good structure stability at 
long time thermal exposure. The associated precipitation or compact morphology of $\gamma^{\prime \prime}+\gamma^{\prime}$ has been studied by many researchers, but little information for the granular phase at grain boundaries is reported. The following work is to identify this granular phase in 718 type alloys.
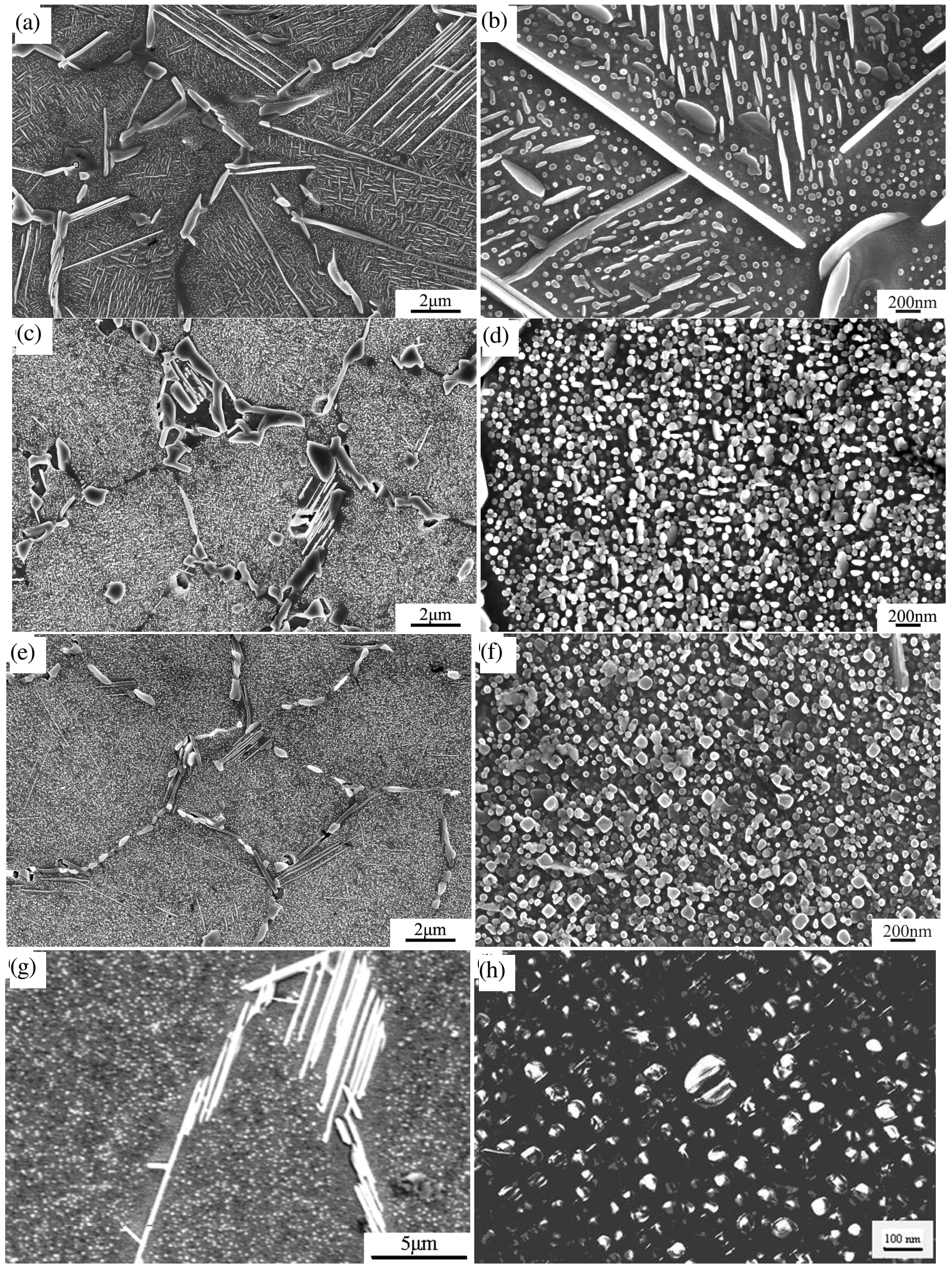
Fig.5 SEM Microstructures of Alloy 1: (a)(b); Alloy 3: (c)(d); Alloy 4: (e)(f); 718Plus: $(\mathrm{g})(\mathrm{h})$ aging at $760^{\circ} \mathrm{C} \times 1000 \mathrm{~h}$

(1) EDS Identification of Grain Boundary Granular Phase in Modified 718 Type Alloys

EDS analyses reveal that the granular phase at grain boundaries is rich in $\mathrm{Nb}$ and Mo for alloys 2 and 4, however, except for $\mathrm{Nb}$ and $\mathrm{Mo}$, it is also rich in $\mathrm{W}$ for alloys 3 and 5. Fig. 6 is the EDS mapping of alloying elements in grain boundary granular phase for Alloy 4.

\section{(2) XRD Identification and Chemical Composition Determination}

Just as mentioned in SEM structure of 718 type alloys, there are granular phase distributed at grain boundaries. In order to identify this phase, XRD was conducted. Figure 7 shows the XRD patterns and phase identification of 718 type alloys at as heat-treated condition, which indicates that there is a group of diffraction pattern of a new phase, different to the familiar phases such as $\delta, \gamma^{\prime}, \gamma^{\prime \prime}$ and MC in conventional 718 Alloy 1.

Physico-chemistry analyses were conducted to determine the chemical composition of $\delta^{\prime \prime}$ phase. The experimental results reveal that the chemical composition of $\delta^{\prime \prime}$ phase for Alloy 2 and Alloy 4 is at the same level and for Alloy 3 and Alloy 5. Table $\amalg$ lists the chemical composition of $\delta^{\prime \prime}$ phase in different modified 718 type alloys. The analysis indicates that $\delta^{\prime \prime}$ phase is rich in $\mathrm{Nb}$ and Mo for Alloys 2 and 4 and $\mathrm{W}$ rich in $\delta^{\prime \prime}$ phase for Alloys 3 and 5, the $\mathrm{W}$ containing alloys. These experimental results are consistent with EDS analyses.
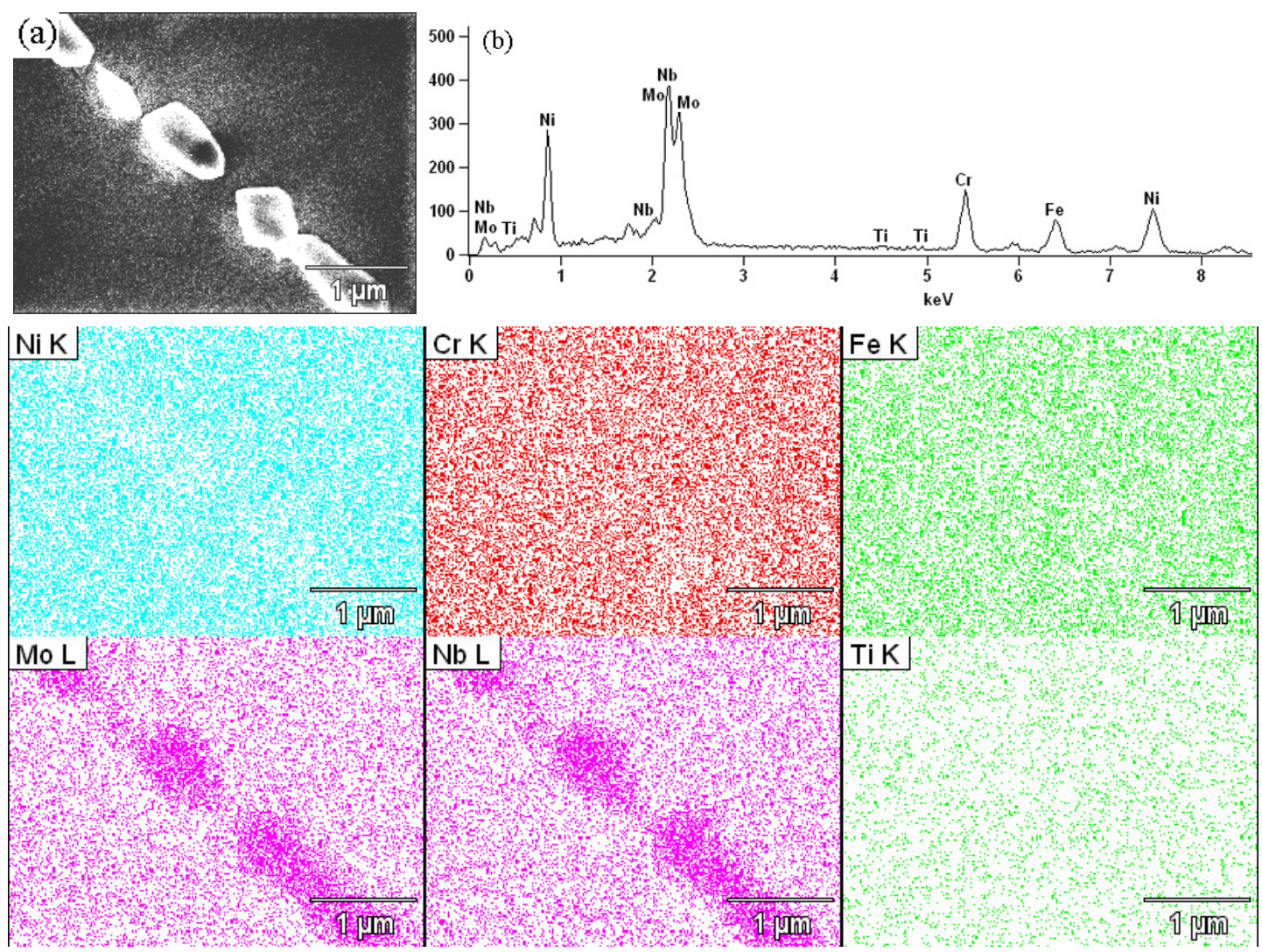
Fig.6 EDS mapping of alloying elements distribution at grain boundary granular phase in Alloy 4
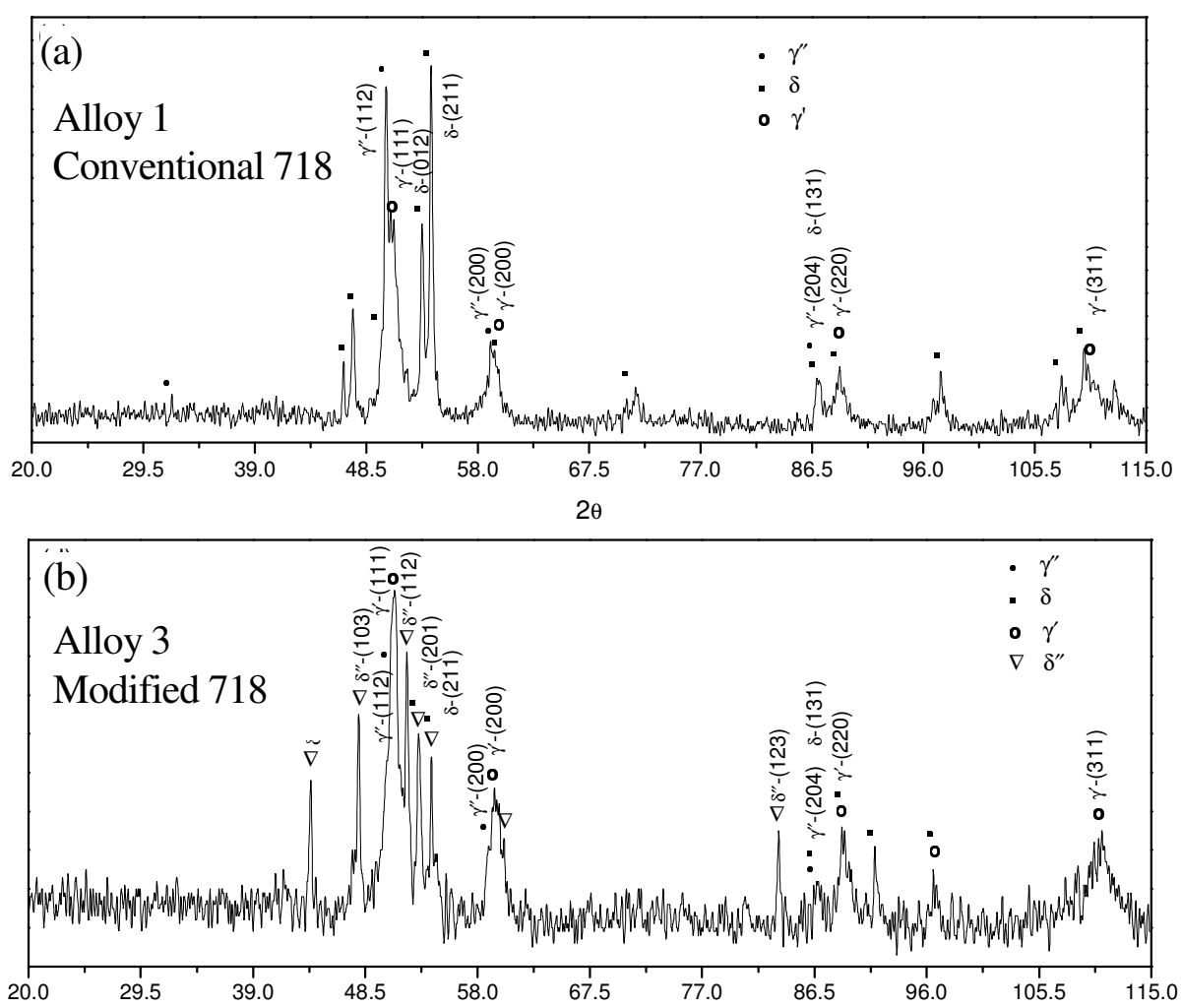

$2 \theta$
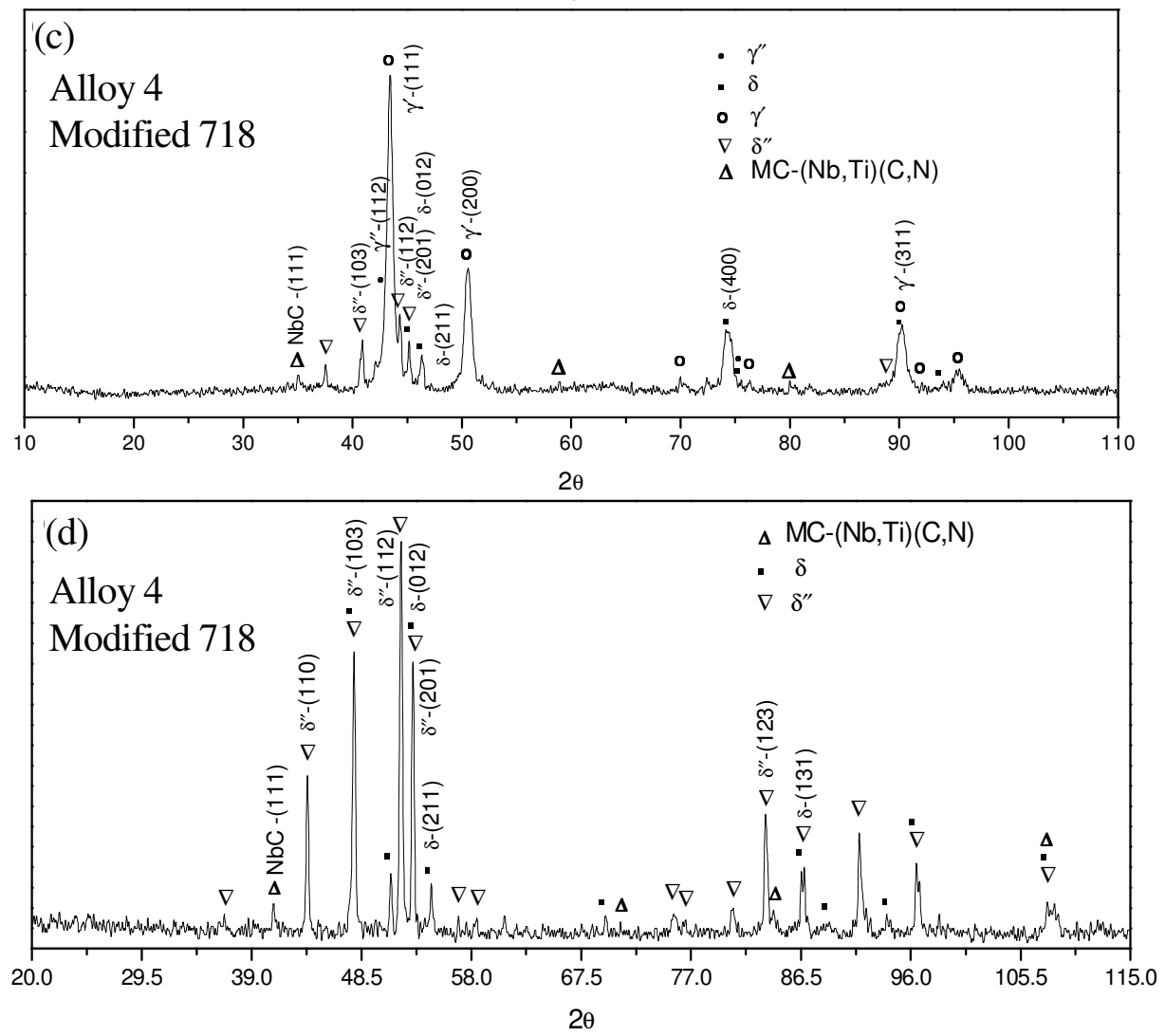
Fig.7 XRD identifications of (a) Alloy 1; (b) Alloy 3; (c)(d)Alloy 4

Table $\amalg$ The chemical composition of $\delta^{\prime \prime}$ phase determined by physico-chemistry analyses (at $\%$ )

\begin{tabular}{|c|c|c|c|c|c|c|c|}
\hline Alloy & $\mathrm{Ni}$ & $\mathrm{Fe}$ & $\mathrm{Cr}$ & $\mathrm{Mo}$ & $\mathrm{W}$ & $\mathrm{Nb}$ & $\mathrm{Ti}$ \\
\hline 2 & 34.65 & 15.69 & 18.83 & 9.88 & - & 20.47 & 0.49 \\
3 & 28.56 & 18.89 & 19.22 & 9.18 & 2.39 & 20.37 & 1.39 \\
4 & 32.83 & 15.35 & 19.41 & 10.85 & - & 20.92 & 0.66 \\
5 & 27.49 & 19.17 & 20 & 9.89 & 2.53 & 20.01 & 0.91 \\
\hline
\end{tabular}

Mechanical Properties of 718 Type alloys at Heat Treated Condition and After Long Time Aging

(1) Mechanical Properties of 718 Type Alloys at Heat Treated Condition

The tensile properties of 718 type alloys determined at 20,650 and $680^{\circ} \mathrm{C}$ are shown in Fig. $8.20^{\circ} \mathrm{C}$ and $650^{\circ} \mathrm{C}$ the ultimate tensile strength and yield strength for the 718 type alloys are comparable with conventional 718 alloy. Modified 718 type alloys, with higher Al content, exhibit higher ultimate tensile strength and yield strength at test temperature $680^{\circ} \mathrm{C}$ than the conventional composition.

Stress rupture tests were conducted at $680^{\circ} \mathrm{C}$ and $690 \mathrm{MPa}$. The results, shown in fig 9, indicate that stress rupture life for Alloy 2 and Alloy 4 is almost twice as compared to conventional 718 Alloy 1. Alloy 3 and Alloy 5, with W addition, is also superior to Alloy 1.

Fatigue crack growth rate testing of 718 type alloys were conducted and compared with conventional 718 Alloy 1 . The test specimens were carefully prepared to produce the same grain sizes. Cyclic stress testing was performed at $650^{\circ} \mathrm{C}$ with initial $\Delta \mathrm{K}=20 \mathrm{MPa}^{\circ} \mathrm{m}^{1 / 2}$ and $90 \mathrm{~s}$ dwelling time. The experimental results are plotted in Fig.10. Under these test conditions the fatigue crack propagation rates of the modified 718 type alloys (Alloy 2, Alloy 3 and Alloy 4) are all remarkable lower than that of conventional 718, Alloy 1 . It is believed that $\delta^{\prime \prime}$ phase formation at grain boundaries and the associated or compact morphology precipitation of $\gamma^{\prime \prime}+\gamma^{\prime}$ phases plays a key role for decreasing fatigue crack growth rate.

(2) Mechanical Properties of 718 Type alloys After Long Time Aging

Our experimental results reveal that alloying element modifications have a noticeable effect on structure stability. This is demonstrated by the improved elevated temperature mechanical properties, Fig.11 and Fig.12. 

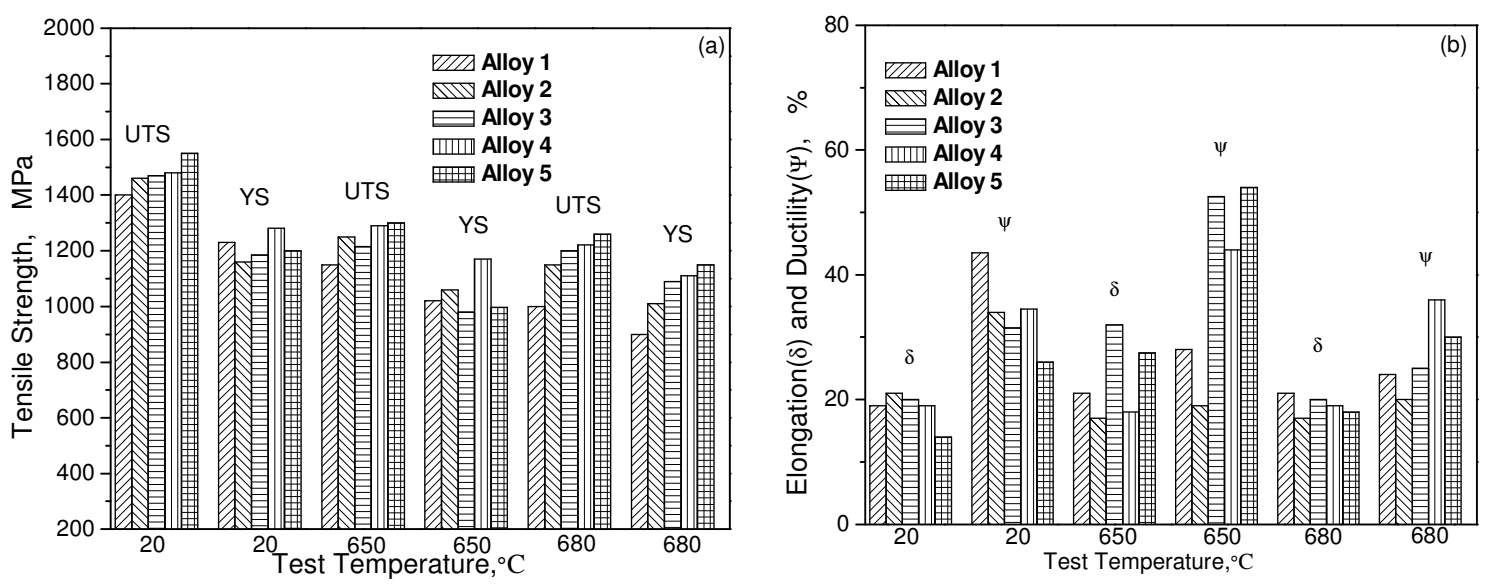

Fig.8 Tensile properties of 718 type alloys (a) Tensile strength (b) Elongation and ductility

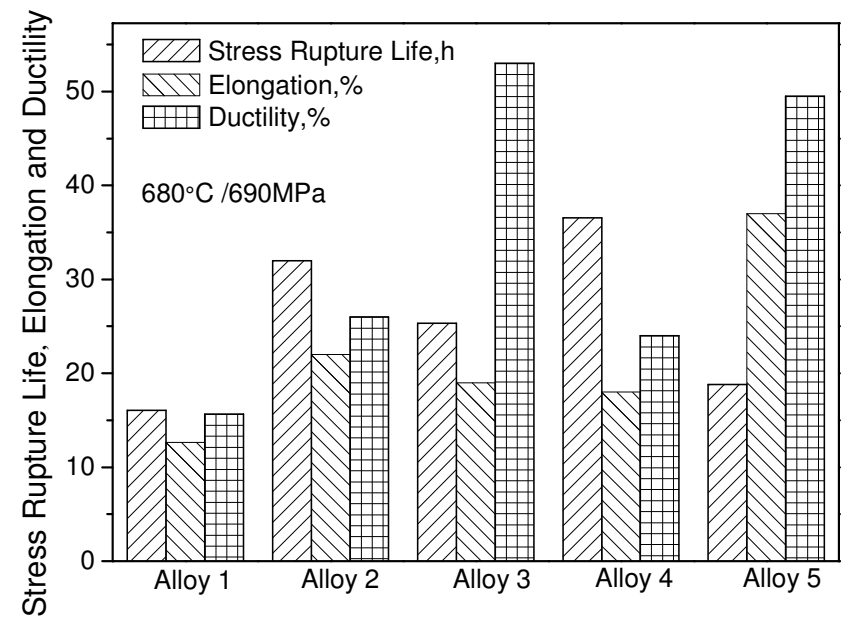

Fig.9 Stress rupture properties of 718 type alloys

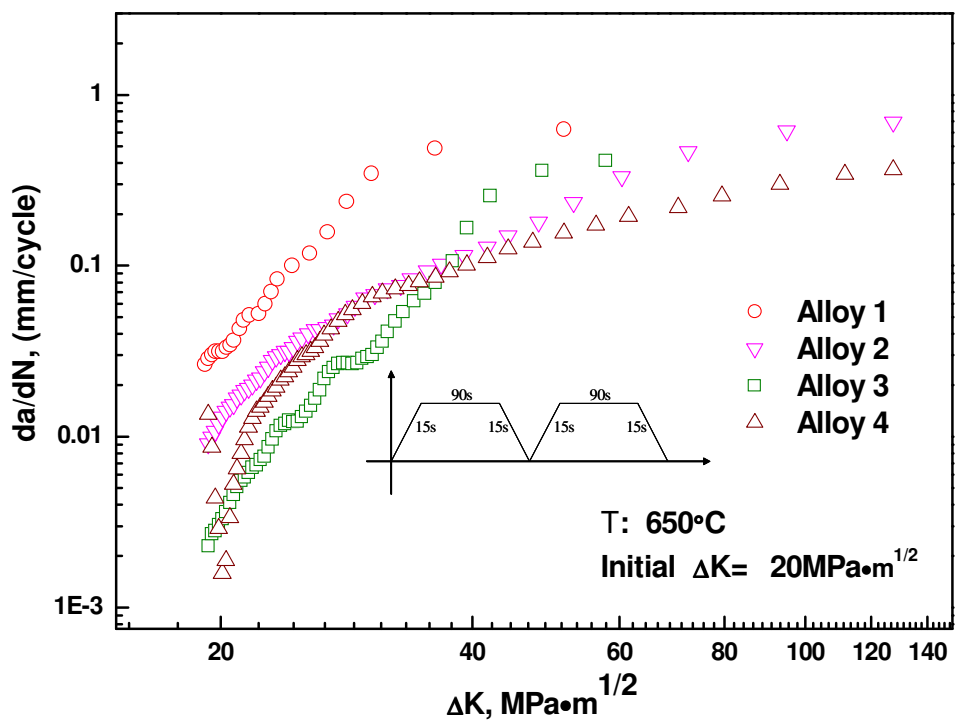

Fig.10 Fatigue crack propagation behaviors of 718 type alloys at $650^{\circ} \mathrm{C}$ cyclic stress condition in comparison with conventional 718 Alloy 1 

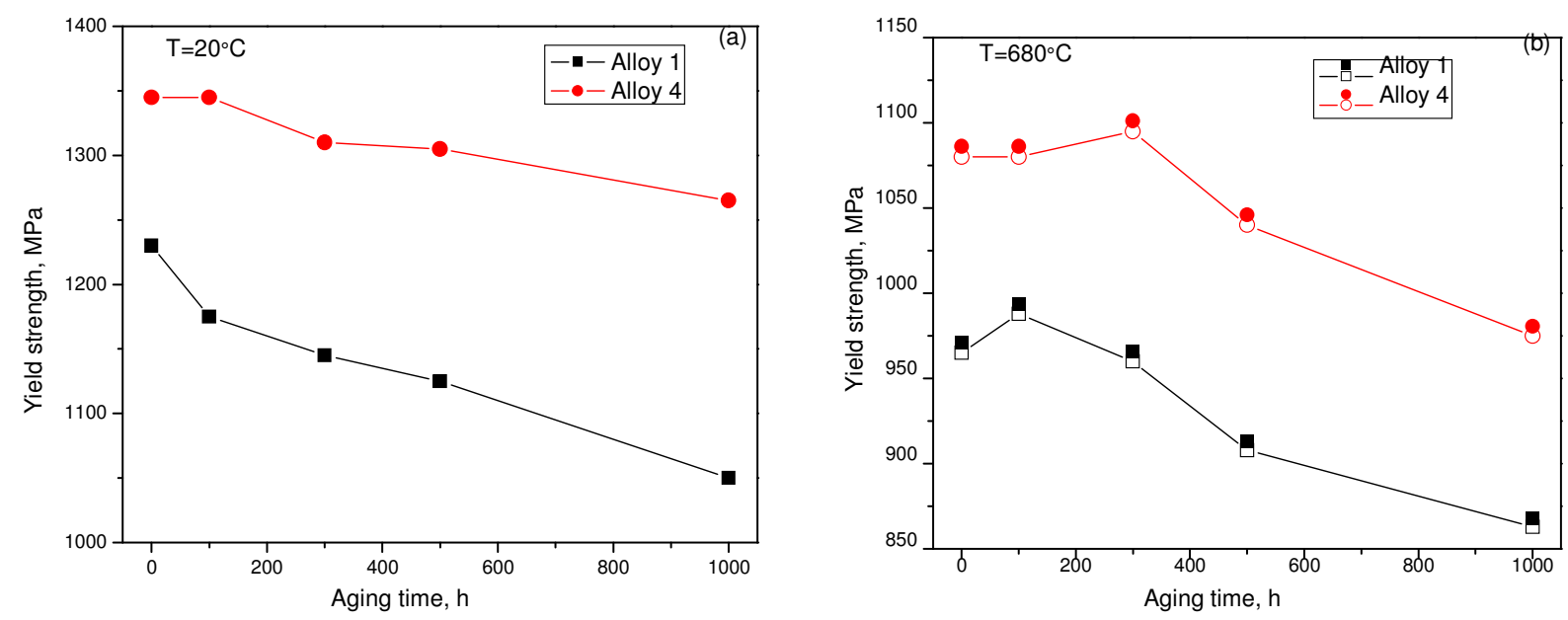

Fig.11 The effect of thermal exposure at $680^{\circ} \mathrm{C}$ on tensile properties (a) $25^{\circ} \mathrm{C}$ and (b) $680^{\circ} \mathrm{C}$
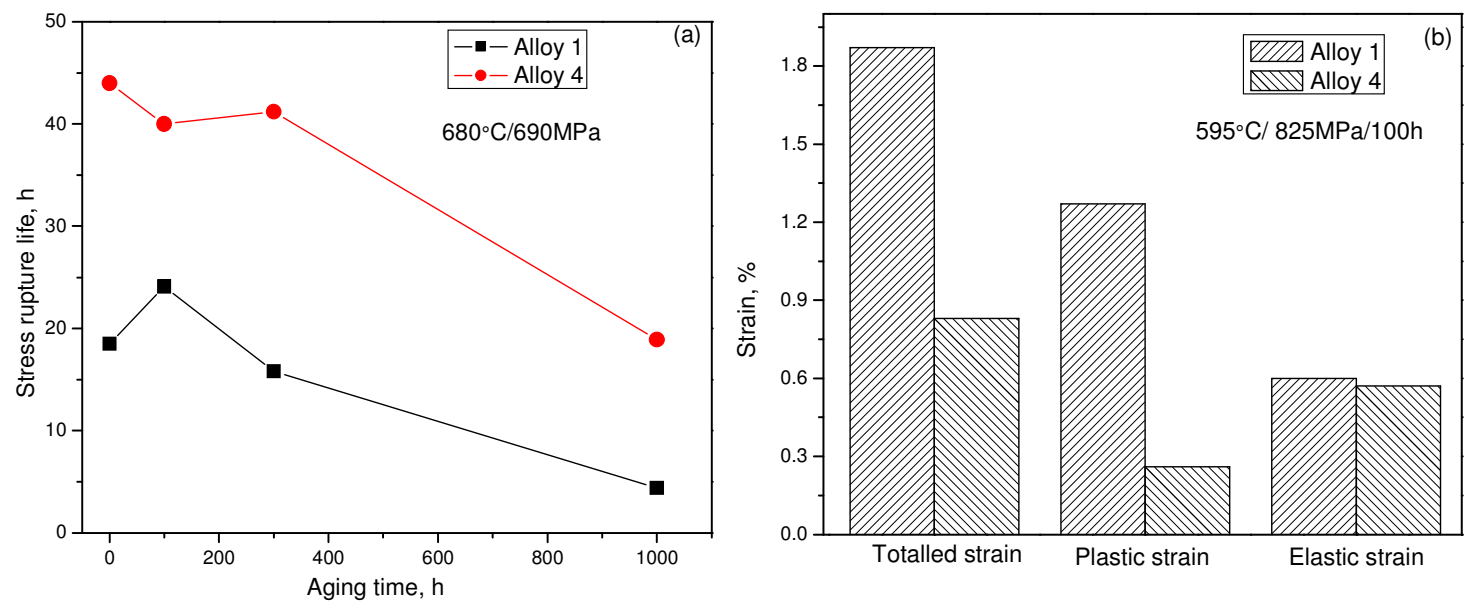

Fig.12 The effect of thermal exposure on (a) stress rupture and (b) creep properties

\section{Discussions}

Our study shows that the chemical composition modifications of $\mathrm{Al}$ content and $\mathrm{W}$ addition change the phase precipitation behaviors from needle-like $\delta$ phase and separate precipitation of disk-like $\gamma^{\prime \prime}$ and globular $\gamma^{\prime}$ phase in conventional 718 Alloy 1 to granular $\delta^{\prime \prime}$ phase with a small fraction of needlelike $\delta$ phase, and associated or compact morphology precipitation of $\gamma^{\prime \prime}$ and $\gamma^{\prime}$ phase in modified 718 type alloys (Alloys 2, 3, 4, 5). The 718 type alloys with granular $\delta^{\prime \prime}$ phase at grain boundaries and compact morphology precipitation of $\gamma^{\prime \prime}$ and $\gamma^{\prime}$ phase characterize with superior combination of structure stability and mechanical properties during long time thermal exposure at temperatures above $650^{\circ} \mathrm{C}$. Thermodynamic calculation results indicate that with the increase of Al content, $\gamma^{\prime}$ phase solvus temperature increases remarkably $\left(1 \% \mathrm{~W}\right.$ addition has minor effect on $\gamma^{\prime}$ phase solvus temperature). The $\gamma^{\prime}$ solvus temperature for conventional 718 Alloy 1 is $904^{\circ} \mathrm{C}$, however, it is about $963^{\circ} \mathrm{C}$ for Alloy 2 and 4 , and it is $947^{\circ} \mathrm{C}$ and $974^{\circ} \mathrm{C}$ for Alloy 3 and 5 respectively.

Physico-chemistry analyses results show that $\delta^{\prime \prime}$ phase is rich in alloying element with higher solvus temperature such as $\mathrm{Nb}$ and $\mathrm{Mo}(\mathrm{W})$ (Table $\amalg)$. Our experimental results indicate that $\delta^{\prime \prime}$ phase solvus 
temperature is near to $1040^{\circ} \mathrm{C}$, which is higher than that of $\delta$ phase in conventional 718 Alloy $1\left(1010^{\circ} \mathrm{C}\right)$ [28]. Therefore, chemical composition adjustment not only on $\mathrm{Nb}$ and $\mathrm{Ti}$ but also on $\mathrm{Al}$ has a good effect on the improvement of phase solvus temperatures.

Quantitative phase fractions results are listed in Table IV. It can be achieved that increasing $\mathrm{Al}$ content can obviously promote the formation of $\gamma^{\prime \prime}+\gamma^{\prime}$ phase and remarkably restrain $\delta$ phase formation. The fractions of MC phase in these alloys are almost equal to each other. Another fact should be noted is that the fraction of $\delta^{\prime \prime}$ phase increases with the increment of $\mathrm{Al}$ content and it appears that greater fraction of $\delta^{\prime \prime}$ phase is consistent with the absence of $\delta$ phase. Therefore, it seems that higher Al content can promote the formation of $\gamma^{\prime \prime}+\gamma^{\prime}$ and granular $\delta^{\prime \prime}$ phase, but restrain $\delta$ phase formation. The fraction of $\delta^{\prime \prime}$ phase in Alloy 2 and Alloy 3 is $0.85 \%$ and $2.88 \%$ respectively. The main difference of chemical composition in these two alloys is that Alloy 3 has $1.5 \% \mathrm{~W}$ addition. Therefore tungsten is another alloying element to promote $\delta^{\prime \prime}$ phase formation. This is in agreement with the results by thermodynamic calculation [28].

Table IV Different phase fractions in modified 718 type alloys after heat treatment via physico-chemistry analyses (wt\%)

\begin{tabular}{|c|c|c|c|c|}
\hline Alloy & $\gamma^{\prime}+\gamma^{\prime \prime}$ & $\delta$ & $\delta^{\prime \prime}$ & MC \\
\hline 1 & 14.62 & 2.92 & - & 0.096 \\
2 & 16.99 & 2.06 & 0.85 & 0.091 \\
3 & 16.71 & 1.17 & 2.88 & 0.093 \\
4 & 17.53 & 0.82 & 2.11 & 0.096 \\
5 & 19.58 & - & 5.36 & 0.091 \\
\hline
\end{tabular}

\section{Conclusions}

(1) It is remarkable that increasing $\mathrm{Al}$ content and $\mathrm{W}$ addition not only retards but also significantly restrains $\delta$ phase formation and promotes more stable $\delta^{\prime \prime}$ phase formation. Moreover, separate precipitation of $\gamma^{\prime \prime}$ and $\gamma^{\prime}$ is substituted by associated precipitation of $\gamma^{\prime \prime}+\gamma^{\prime}$ in modified 718 type alloys and the coarsening rate of the later is much lower than that of the former. $\delta^{\prime \prime}$ phase is rich in $\mathrm{Nb}$ and $\mathrm{Mo}(\mathrm{W})$ and characterizes with stable behavior during long time thermal exposure.

(2) The 718 type alloys with higher Al content display better microstructural stability and mechanical properties than conventional 718 alloy.

(3) In order to achieving modified 718 type alloy with higher strength, superior stress rupture life and structure stability at $680^{\circ} \mathrm{C}$ or higher temperatures, suggested chemical composition modification should be controlled in the range of $0.8 \sim 1.3 \% \mathrm{Al}, 5.3 \sim 5.5 \% \mathrm{Nb}, 0.013 \sim 0.015 \% \mathrm{P}, 0.005 \sim 0.01 \% \mathrm{~B}$ respectively. 


\section{References}

1. R.E. Schafrik, D.D. Ward and J.R. Grod, "Application of Alloy 718 in GE Aircraft Engines: Past, Present and Next Five Years," Superalloys 718, 625, 706 and Various Derivatives, ed. E.A. Loria (Warrendale, PA: TMS, 2001), 1-11.

2. D.F. Paulonis and J.J. Schirra, "Alloy 718 Pratt \& Whitney- Historical Perspective and Future Challenges," Superalloys 718, 625, 706 and Various Derivatives, ed. E.A. Loria (Warrendale, PA: TMS, 2001), 13-23.

3. R. Cozar and A. Pineau. "Morphology of $\gamma$ and $\gamma^{\prime}$ Precipitates and Thermal Stability of Inconel 718 Type Alloys," Metallurgical Transactions, 4 (1973), 47-59.

4. E. Andrieu et al., "Influence of Compositional Modifications on Thermal Stability of Alloy 718," Superalloys 718, 625, 706 and Various Derivatives, ed. E.A. Loria (Warrendale, PA: TMS, 1994), 695-710.

5. J.P. Collier, A.O. Selius and J.K. Tien, "On Development a Microstructurally and Thermally Stable Iron-Nickel Base Superalloy," Superalloys 1988, ed. S. Reichman et al. (Warrendale, PA: TMS, 1988), 43-52.

6. J.P. Collier et al., "The Effect of Varying Al, Ti, and Nb Content on the Phase Stability of Inconel 718," Metallurgical Transactions A, 19A (1988), 1657-1688.

7. J.K. Tien, J.P. Collier and G. Vigonoul, "The Roll of Niobium and Other Refractory Elements in Superalloy 718," Superalloy 718-Metallurgy and Applications, ed. E.A. Loria (Warrendale, PA: TMS, 1989), 553-566.

8. J.A. Manriquez et al., "The High Temperature Stability of 718 Derivative alloys," Superalloys 1992, ed. S.D. Antolovich et al. (Warrendale, PA: TMS, 1992), 507-516.

9. E.C. Guo, F.Q. Xu and E.A. Loria, "Improving Thermal Stability of Alloy 718 Via Small Modifications in Composition," Superalloys 718, 625, 706 and Various Derivatives. ed. E. A. Loria (Warrendale, PA: TMS, 1989), 567-576.

10. E.C. Guo, F.Q. Xu and E.A. Loria, "Effect of Heat Treatment and Compositional Modification on Strength and Thermal Stability of Alloy 718," Superalloys 718, 625, 706 and Various Derivatives, ed. E.A. Loria (Warrendale, PA: TMS, 1991), 389-396.

11. E.C. Guo, F.Q. Xu and E.A. Loria, "Further Studies on Thermal Stability of Modified 718 alloys," Superalloys 718, 625, 706 and Various Derivatives, ed. E.A. Loria (Warrendale, PA: TMS, 1994), 721-734.

12. S.A. Loewenkamp and J.F. Radavich, "Microstructure and Properties of Ni-Fe Base Ta-718," Superalloys 1988, ed. S. Reichman et al. (Warrendale, PA: TMS, 1988), 53-62. 
13. K.M. Chang and AH. Nahm, "Rene' 220: $100^{\circ} \mathrm{F}$ Improvement over Alloy 718," Superalloy 718Metallurgy and Applications, ed. E.A. Loria (Warrendale, PA: TMS, 1989), 631-646.

14. K.M. Chang, "Metallurgical Control of Fatigue Crack Propagation in Alloy 718," Superalloys 718, 625, 706 and Various Derivatives, ed. E.A. Loria (Warrendale, PA: TMS, 1991), 447-456.

15. J.R. Groh and J.F. Radavich, "Effects of Iron, Nickel, and Cobalt on Precipitation Hardening of Alloy 718," Superalloys 718, 625, 706 and Various Derivative, ed. E.A. Loria (Warrendale, PA: TMS, 1991), 351-361.

16. W.D. Cao and R.L. Kennedy, "Thermal Stability of Alloys 718 and Allvac 718-ER ${ }^{\circledR}, "$ Superalloys 718, 625, 706 and Various Derivative, ed. E.A. Loria (Warrendale, PA: TMS, 2001), 455-488.

17. W.D. Cao and R.L. Kennedy, "Improving Stress Rupture Life of Alloy 718 by Optimizing Al, Ti, P and B contents," Superalloys 718, 625, 706 and Various Derivative, ed. E.A. Loria (Warrendale, PA: TMS, 2001), 477-487.

18. Zhuangqi Hu, Hongwei Song and Shouren Guo, "Role of P, S and B on Creep Behavior of Alloy 718," Journal of Materials Science \& Technology, 17(4) (2001), 399-402.

19. Na Li, Wenru Sun and Yan Xu, "Effect of P and B on the Creep Behavior of Alloy 718," Materials Letters, 60(17/18) (2006), 2232-2235.

20. J.X. Dong, X.S. Xie and S.H. Zhao, "Enhancement of Thermal Structure Stability in a Ni-Base Superlloy," Scripta Metallurgica. 28 (1993), 1477-1482.

21. X.S. Xie et al., "High Temperature Structure Stability Study on Nb-Containing Nickel-Base Superalloys," Materials Science Forum, 546-549 (2007), 1281-1288.

22. J.X Dong, R.G. Thompson and X.S. Xie, "Multi-Component Intergranular and Interfacial Segregation in Alloy 718 with Correlations to Stress Rupture Behavior," Superalloys 718, 625, 706 and Various Derivatives, ed. E.A. Loria (Warrendale, PA: TMS, 1997), 553-566.

23. Xishan Xie et al., "Segregation Behavior of Phosphorus and Effect on Microstructure and Mechanical Properties in Alloy System Ni-Cr-Fe-Mo-Nb-Ti-Al," Superalloys 718, 625, 706 and Various Derivatives, ed. E.A. Loria (Warrendale, PA: TMS, 1997), 531-542.

24. X. Xie et al., "The Role of Phosphorus and Sulfur in Inconel 718," Superalloys 1996, ed. Kissinger et al. (Warrendale, PA: TMS, 1996), 599-606.

25. W.D. Cao and R.L.Kennedy, "Role of Chemistry in 718-Type Alloys-Allvac ${ }^{\circledR} 718$ Plus ${ }^{\mathrm{TM}}$ alloy Development," Superalloys 2004, ed. K.A. Green et al. (Warrendale, PA: TMS, 2004), 91-99. 
26. X.S. Xie et al., in: E.A. Loria (Ed.), "Structure Stability Study on a Newly Developed NickelBase Superalloy-Allvac ${ }^{\circledR} 718$ Plus ${ }^{\mathrm{TM}}$," Superalloys 718, 625, 706 and Various Derivatives, ed. E.A. Loria (Warrendale, PA: TMS, 2005), 179-191.

27. R.L. Kennedy, “Allvac ${ }^{\circledR} 718$ Plus ${ }^{\mathrm{TM}}$, Superalloy for the Next Forty Years," Superalloys 718, 625, 706 and Various Derivatives, ed. E.A. Loria (Warrendale, PA: TMS, 2005), 1-14.

28. S.H. Fu et al., "Alloy Design and Development of INCONLE 718 Type alloy," Materials Science and Engineering A, 499 (2009), 215-220. 